Instructions/Template for Preparing Manuscript for Jendela Nursing Journal

\title{
Using Mobile Technology in Continuing Nursing Education
}

\author{
Yuni Susiana Nur ${ }^{1}$, Tuti Nuraeni ${ }^{1}$ \\ ${ }^{1}$ Nursing Faculty, Universitas Indonesia \\ Coresponding author: ysusiananur@gmail.com
}

\begin{abstract}
Background: The development of technology after the industrial revolution, digital technology has brought changes in many aspects of life. Nurses as professionals who must always maintain and enhance their knowledge and skills are expected to be able to take advantage of the development of digital technology for the development of professionalism. This article presents a literature review that will explore the use of digital technology in Continuing Nursing Education.

Purpose: The purpose of this research is to find out whether Continuing Professional Education can use digital technology.

Methods: This type of research uses the PICO research tool (population, intervention, comparison, outcome) which is part of the literature review. The question used is whether the use of mobile technology by nurses can be applied in Continuing Professional Education activities.

Results: Research with this literature review shows that the use of digital technology in Continuing Nursing Education is a transformation of the professional learning model that is very possible in professional nursing practice.

Conclusion: The use of digital technology in contemporary nursing practice for the purpose of learning and teaching and expanding knowledge is made possible through the transformation of digital knowledge in real time at work. There needs to be readiness from individual nurses, systems, and organizations to be able to optimize the use of digital technology in Continuing Nursing Education.
\end{abstract}

Keywords:

Continuing Nursing Education; Professional Development; Mobile Digital.

\section{LATAR BELAKANG}

Perkembangan teknologi telah menggeser zaman dari era industri menuju era teknologi informasi (pasca industri). Teknologi informasi adalah suatu teknologi yang digunakan untuk mengolah data, termasuk memproses, mendapatkan, menyusun, menyimpan, memanipulasi data dalam berbagai cara untuk menghasilkan informasi yang berkualitas, yaitu informasi yang relevan, akurat, dan tepat waktu, yang digunakan untuk keperluan pribadi, bisnis, dan pemerintahan dan merupakan informasi strategis untuk mengambil keputusan (Wardiana, 2002). Perkembangan teknologi informasi ini berfokus pada informasi dengan menggunakan telekomunikasi dan informatika sebagai teknologi kunci (enabler technology). Pesatnya perkembangan teknologi informasi ini 
menghasilkan cara-cara baru yang lebih efisien untuk memenuhi kebutuhan hidup melalui penggunaan elektronik, tidak hanya dibidang ekonomi produksi (e-commerce) tetapi juga dibidang lain seperti pendidikan (e-education/e-learning/e-journal) dan kesehatan (e-medicine/e-laboratory).

Pemanfaatan teknologi digital melalui penggunaan metode e-learning pada perangkat komputer di bidang kesehatan, khususnya keperawatan telah dimulai di Amerika sejak tahun 1980-an melalui penelitian pertama yang dilakukan oleh International Medical Informatika Association pada konferensi tentang Dampak dari Komputer di Keperawatan yang diadakan di Inggris pada 1982 (C. A. Mather, Gale, \& Cummings, 2017a). Namun penggunaan mobile learning dalam pembelajaran informal dan Continuing Professional Development (CPD) di pelayanan kesehatan dirasakan sangat lambat. Penelitian sebelumnya menunjukkan ada sistem, organisasi, dan hambatan individu yang telah memberikan kontribusi terhadap kurangnya realisasi dari potensi untuk mentransfer pengetahuan digital dan mengubah model belajar di pelayanan keperawatan. Dalam hal keterbatasan individu, hambatan yang dirasakan adalah perawat yang kurang percaya diri dalam menggunakan teknologi informasi, dimana tercatat perbedaan generasi milenial dengan generasi baby boomer (31\%) yang cenderung tidak terampil menggunakan teknologi digital (C. Mather \& Cummings, 2017).

Perawat dalam menjalankan praktik harus senantiasa menjaga dan meningkatkan mutu pelayanan profesi dengan mengikuti perkembangan ilmu pengetahuan dan teknologi melalui pendidikan dan pelatihan sesuai tugasnya. Hal ini sesuai dengan Undang Undang no 36 th 2009 pasal 24 ayat (2) menyatakan : Ketentuan mengenai kode etik dan standar profesi siatur oleh organisasi profesi. Sementara itu Peraturan Menteri Kesehatan RI No. HK.02.02/MENKES/148/I/2010 Tentang Izin Penyelenggaraan Praktik Perawat, pasal 12 ayat 2 menyatakan : Perawat dalam menjalankan praktik senantiasa meningkatkan mutu pelayanan profesinya dengan mengikuti perkembangan ilmu pengetahuan dan teknologi melalui pendidikan dan pelatihan sesuai tugasnya, yang diselenggarakan oleh Pemerintah atau organisasi profesi (PPNI, 2013).

Pengembangan Keprofesian Berkelanjutan (PKB) atau Continuing Professional Development (CPD) adalah proses pengembangan keprofesian yang meliputi berbagai kegiatan yang dilakukan seseorang dalam kapasitasnya sebagai perawat praktisi, guna mempertahankan dan meningkatkan profesionalismenya sebagai seorang perawat sesuai standar kompetensi yang ditetapkan. Kegiatan PKB dapat berupa pengalaman memberikan asuhan keperawatan, mengikuti pendidikan/ pelatihan, menulis artikel, melakukan penelitian ataupun publikasi karya ilmiah. Pengembangan keprofesian berkelanjutan bagi perawat ini Kesehatan pasal 27 yang menyatakan : Tenaga kesehatan dalam melaksanakan tugasnya berkewajiban mengembangkan dan meningkatkan pengetahuan dan keterampilan yang dimiliki dengan tujuan menjamin mutu keperawatan yang diberikan (PPNI, 2013). Pengertian ini sesuai dengan definisi Continuing Professional Development (CPD) menurut Nursing and Midwifery Board of Australia, Pendidikan Keperawatan Berkelanjutan (PKB) atau Continuing Professional Development (CPD) merupakan sarana bagi seorang profesional dalam rangka memelihara, meningkatkan dan memperluas pengetahuan, keahlian dan kompetensi, serta mengembangkan kualitas pribadi dan profesional yang diperlukan dalam 
kehidupan professional (Ardian, 2017). Organisasi profesi keperawatan di Cina mengistilahkan PKB sebagai Continuing Nursing Educataion (CNE) yaitu pendidikan profesioanal berkelanjutan adalah pembelajaran terus menerus seumur hidup mengacu pada mempromosikan atau meningkatkan pengetahuan, keterampilan, dan sikap perawat (Lindsay, Oelschlegel, \& Earl, 2017).

Pedoman PKB menurut PPNI mengatur bagaimana perawat mengembangkan diri melalui; 1) Kegiatan praktik professional dengan memberikan pelayanan keperawatan baik berupa praktik di institusi pelayanan kesehatan maupun praktik mandiri di luar institusi serta membimbing praktik mahasiswa di klinik maupun di masyarakat, 2) Pendidikan berkelanjutan dengan mengikuti temu ilmiah, seminar, workshop, pelatihan, 3) Pengembangan ilmu pengetahuan dengan melakukan penelitian, publikasi hasil penelitian di jurnal, menulis artikel di jurnal, menulis buku dan dipublikasikan, 4) Pengabdian masyarakat dengan berpartisipasi dalam pemberdayaan masyarakat melalui kegiatan social, memberikan penyuluhan, penanggulangan bencana, terlibat aktif dalam pengembangan profesi, anggota pokja kegiatan keprofesian (PPNI 2013).

\section{TUJUAN}

Pentingnya CPD dalam meningkatkan profesionalisme tenaga keperawatan telah dikembangkan oleh banyak penelitian yang berfokus pada konten yang memuat instrument penilaian CPD dan cara-cara mengakses perkembangan ilmu pengetahuan, teknis asuhan maupun riset. Untuk itu literature review ini dimaksudkan untuk mengetahui cara-cara lain yang meemungkinkan dapat digunakan untuk meningkatkan profesionalisme tenaga keperawatan melaui pembelajaran mobile.

\section{METODE}

Penelitian ini menggunakan literature review dengan perangkat PICO (population, intervention, comparison dan outcome). Perangkat ini didesain untuk membantu peneliti saat membuat pertanyaan penelitian dan memungkinkan mendapatkan kajian literatur yang lebih khusus. Pertanyaan penelitiannya adalah: 'apakah mobile technology dapat digunakan dalam kegiatan pendidikan dan pengembangan professional berkelanjutan ?'

Perangkat pertanyaan:

Populasi : penelitian yang membahas mobile technology dalam upaya pendidkan keprofesian berkelanjutan

Intervensi : mobile technology

Comparison : model pembelajaran tradisional

Outcome : model pembelajaran alternative melalui mobile technology

Pertanyaan penelitian: 'apakah mobile technology dapat menjadi model pembelajaran alternative untuk pendidikan dan pengembangan professional berkelanjutan ?'

Adapun sumber yang dapat diakses untuk penelitian adalah JKI, EBSCO, ProQuest, Elsevier dengan kata kunci mobile technology, e-learning, pendidikan keprofesian berkelanjutan, continuing professional development, nursing. Kriteria inklusi pada penelitian ini adalah: sumber data 5 tahun terakhir, digital technology, mobile technology, e-learning, pendidikan keprofesian berkelanjutan, continuing professional development. Sedangkan kriteria eklusi yaitu: nursing students, sumber data dibawah tahun 2016. 


\section{HASIL}

Pembelajaran Mobile didefinisikan sebagai pembelajaran dan pengajaran interaksi yang memperhitungkan mobilitas peserta didik, belajar dan teknologi termasuk perangkat genggam mobile seperti notebook elektronik, tablet atau smartphone. Istilah ini digunakan untuk menggambarkan pembelajaran mobile yang dilakukan di area praktik perawatan, yang penting karena mengakses informasi dilakukan di manapun perawat berada, daripada pembelajar yang perlu secara fisik pergi ke tempat lain seperti perpustakaan atau meja komputer untuk mengakses informasi (C. A. Mather, Gale, \& Cummings, 2017b). Study yang meneliti tentang cara-pemanfaatan teknologi digital dalam hal mobile learning untuk kegiatan pembelajaran dan Continuing Professional Development (CPD) dikembangkan melalui strategi digital di tingkat teknik, kontekstual maupun emansipatory level baik itu dalam bentuk tatap muka, workshop, conference, belajar online serta menyimpan portofolio sehingga perawat dapat mengetahui dan mendokumentasikan CPD yang sudah dilakukan (C. Mather \& Cummings, 2017).

Penggunaan digital technology dalam praktik keperawatan membutuhkan kesiapan, kepercayaan dan kemampuan perawat. Apalagi bagi perawat supervisor yang mempunyai peran dalam melakukan bimbingan pengajaran dan pembelajaran dimana perawat supervisor menjadi model profesional literasi digital dan literasi ehealth untuk mentransfer pengetahuan digital secara real time di tempat kerja untuk meningkatkan praktek keperawatan yang mengakses pada evidence-base yang diperlukan. Expanding technology yang dapat dilakukan oleh perawat supervisor dalam hal pengembangan professional digital yaitu; 1) Evidence of learning, 2) Digital literasy, 3) Acces to mobile technology. Penelitian yang dilakukan pada perawat supervisor di 2 negara bagian Australia ini memperkuat peran perawat supervisor sebagai model professional digital untuk memajukan praktik keperawatan melalui evidence-base secara real time di tempat kerja (C. Mather \& Cummings, 2017). The Australian Nursing and Midwifery Accreditation Council memberikan arahan bahwa semua program keperawatan terakreditasi dianjurkan memasukan nursing informatics (C. A. Mather et al., 2017b). PPNI secara implisit juga menyebutkan bahwa pendidikan dan pelatihan yang dilakukan perawat mengikuti perkembangan ilmu pengetahuan dan teknologi (PPNI, 2013). PPNI sebagai organisasi profesi juga telah menggunakan teknologi digital berupa video on line dalam transfer knowledge tentang tatacara mengurus atau memperpanjang surat tanda registrasi (STR).

Transformasi terhadap perubahan cara belajar dan pengembangan diri perawat, dibuktikan oleh beberapa penelitian, diantaranya penelitian yang dilakukan dengan menggunakan 2.826 populasi perawat dari beberapa RS sekunder dan tersier di Beijing, dengan metode penelitian survey distribusi kuantitatif cross sectional tentang sikap, motivasi, dan hambatan yang dihadapi salam memenuhi kebutuhan Continuing Nursing Education adalah sebagai berikut (Wang et al., 2018). Hasil dari penelitian ini menyatakan sikap positif terhadap CNE sehingga CNE dirasakan perlu, penting dan praktis. Sedangkan hambatan yang didapat dari survey tersebut terkait biaya, waktu, informasi yang diterima dan lokasi. Harapan mereka adalah e-learning bisa dianggap sebagai platform untuk CNE (Wang et al., 2018). Penelitian sejenis dilakukan pada 3.453 perawat registered ners di tiga RS di Netherlands selama bulan Oktober 2016 s.d 
Maret 2017 dengan metode penelitian study cross sectional diperoleh hasil penelitian sebagai berikut (van Houwelingen, Ettema, Kort, \& Ten Cate, 2019):

1. Responden; Responden dalam penelitian ini perawat baik perawat pria maupun wanita, usia 30 s.d 60 tahun di sejumlah RS di beberapa negara.

2. Tingkat pendidikan; Tingkat pendidikan responden minimal registered nurse

3. Partisipasi perawat yang menggunakan mobile technology

Pada tahun 2017 pada penelitian van Houwelingen et.al 49,5\% perawat berpengalaman menggunakan telehealth dimana 93,9\% menggunakan smartphone, 53,2 \% menggunakan tablet and/or ipad, 97\% menggunakan internet, 95\% menggunakan emal, 81,4 \% menggunakan computer/laptop.

4. Efektifitas mobile technology dalam PKB/CPD/CNE

Hasil penelitian Wang et al., 2018 tentang sikap dan harapan perawat di RS Beijing terhadap Continuing Nursing Education, bentuk pembelajaran adalah 30,6\% kuliah tatap muka, 31,1\% laboratorium, 34,8\% online learning, dan 3,5\% bentuk pembelajaran lainnya.

5. Peran Perawat

Keterlambatan dunia keperawatan menggunakan digital technology dalam model pembelajaran salah satunya disebabkan karena kesiapan dan ketidakpercayaan diri menggunakan digital technology dalam pendidikan dan pengembangan professional berkelanjutan (C. Mather \& Cummings, 2017). Peran perawat supervisor juga sangat penting sebagai model professional digital (C. Mather \& Cummings, 2017). Peran organisai juga tidak kalah penting dalam mengatur tata kelola penggunaan teknologi digital dalam kegiatan PKB (PPNI, 2013), CPD (C. A. Mather et al., 2017b), dan CNE (Wang et al., 2018).

Penelitian lain yang dilakukan untuk menguji alat ukur yang valid dan handal adalah instrument penilaian interpersonal learning sebagai bagian dari CPD. Desain experimental ini berfokus pada kualitas interaksi interpersonal dan perilaku dalam tim yaitu collaboration, coordination, cooperation, communication, dan comendation (Ong, Diño, Maria Minerva, \& Hidalgo, 2019).

\section{PEMBAHASAN}

Pada literature review ini didapatkan suatu gambaran bahwa perubahan era industry menuju era digital informasi telah mempengaruhi transformasi model pembelajaran tradisional kepada digital technology learning. Organisasi profesi keperawataan sebagai lembaga yang diberi wewenang mengatur profesionalitas anggotaanya telah menyusun pedoman pendidikan professional berkelanjutan untuk menjamin tersedianya tenaga keperawatan yang menjaga dan meningkatkan kompetensinya. Seiring dengan perkembangan teknologi informasi, perawat dalam meningkatkan

kompetensinya juga mulai menggunakan model pembelajaran baru dengan memanfaatkan mobile technology (C. A. Mather et al., 2017b). Walaupun penggunaan teknologi digital dalam dunia keperawatan khusunya kegiatan CPD dirasakan terlambat, yang disebabkan oleh system, organisasi dan individu (C. Mather \& Cummings, 2017), namun pengaturan tatakelola digital teknologi dalam CPD sudah mulai dilakukan baik oleh manajemen keperawatan melalui keterlibatan perawat supervisor (C. Mather \& Cummings, 2017) maupun organisasi profesi (C. A. Mather, Cummings, \& Gale, 
2018). Kesiapan individu perawat juga sejalan dengan trend penggunaan mobile technology dalam PKB/CPD (van Houwelingen et al., 2019).

\section{SIMPULAN}

Pemanfaatan digital technology dalam pendidikan professional berkelanjutan mulai dirasakan oleh perawat. Prinsip penggunaan mobile digital dalam praktik keperawatan adalah untuk mendapatkan informasi terkini di area kerja tentang pengetahuan, teknik skill, dan hasil riset sebagai sumber infromasi yang berharga dalam merawat pasien. Selain itu kepraktisan, efektif dan efisien juga menjadi alternative model pembelajaran professional. Hal yang harus diperhatikan dalam menggunakan mobile technology dalam praktik sehari-hari adalah manajemen waktu serta akses terhadap sumber-sumber yang valid dan handal. Hal ini penting karena penggunaan mobile technology di waktu pelayanan dapat menimbulkan penurunan terhadap focus asuhan. Kehandalan dan validitas sumber informasi juga menjadi penting sebagai rujukan informasi yang tepat.

\section{REFERENSI}

Ardian, P., Rr.Tutik Sri Hariyati. (2017). Pendidikan Keperawatan Berkelanjutan Melalui Implementasi Diskusi Refleksi Kasus (Drk): Pilot Study. Jurnal Kesehatan Holistik (The Journal of Holistic Healthcare), Volume II.

Mather, C., \& Cummings, E. (2017). Modelling Digital Knowledge Transfer: Nurse Supervisors Transforming Learning at Point of Care to Advance Nursing Practice. Informatics, 4(2), 12. doi:10.3390/informatics4020012

Mather, C. A., Cummings, E. A., \& Gale, F. (2018). Advancing mobile learning in Australian healthcare environments: nursing profession organisation perspectives and leadership challenges. BMC Nursing, 17(1), 44-13. doi:10.1186/s12912-0180313-Z

Mather, C. A., Gale, F., \& Cummings, E. A. (2017a). Governing mobile technology use for continuing professional development in the Australian nursing profession. BMC Nursing, 16.

Mather, C. A., Gale, F., \& Cummings, E. A. (2017b). Governing mobile technology use for continuing professional development in the Australian nursing profession. BMC Nursing, 16, 17-17. doi:10.1186/s12912-017-0212-8

Ong, I. L., Diño, M. J. S., Maria Minerva, P. C., \& Hidalgo, F. A. (2019). Development and validation of interprofessional learning assessment tool for health professionals in continuing professional development (CPD). PLoS One, 14(1).

PPNI. (2013). Pedoman pengembangan keprofesian berkelanjutan (pkb) perawat indonesia In D. D. P. P. PPNI (Ed.).

van Houwelingen, C. T. M., Ettema, R. G. A., Kort, H. S. M., \& Ten Cate, O. (2019). Hospital Nurses' SelfReported Confidence in Their Telehealth Competencies. Journal of continuing education in nursing, 50(1), 26-34. doi:10.3928/002201242019010207

Wang, Y., Wang, Y., Sun, L., Sun, L., Greene, B., Greene, B., . . Li, C. (2018). Current continuing nursing education among beijing nurses: A cross-sectional study. Journal of continuing education in nursing, 49(11), 526-536. doi:10.3928/00220124-2018101710 